\title{
SPIRITUALITAS SAINS DALAM ISLAM: Mengungkap Teologi Saintifik Islam
}

\author{
Badarussyamsi \\ Fakultas Ushuluddin IAIN Sulthan Thaha Saifuddin \\ Jl. Arif Rahman Hakim Telanaipura, Jambi, Sumatera Selatan, 36124 \\ e-mail: badarussyamsi76@gmail.com, badarussyamsi1976@gmail.com
}

\begin{abstract}
Abstrak: Artikel ini membahas pemikiran Islam tentang teologi saintifik yang sering menjadi perdebatan para ilmuwan. Sebagian pakar berpendapat bahwa al-Qur'an memotivasi umatnya untuk mencintai sains. Pakar lain berpandangan bahwa ayatayat al-Qur'an memberikan sinyal-sinyal sains. Pada perkembangan terakhir menguat geliat umat Islam tentang perlunya islamisasi sains. Pendekatan dalam artikel ini adalah pendekatan teologi sains yang mengupas visi dan relasi sains dan Islam. Dalam konteks ini, Islam bukan hanya mendorong umatnya untuk mencintai sains, akan tetapi memberikan sinyal sains yang kalau diungkap akan menghasilkan karya sains yang memberikan kontribusi bagi peradaban manusia. Penulis menyimpulkan bahwa eksistensi sains memperoleh dukungan signifikan dalam ajaran Islam hingga menjadi bagian integral yang tak terpisahkan dari sistem teologi Islam.
\end{abstract}

\begin{abstract}
The Spirituality of Science in Islam: Revealing Islamic Scientific Theology. This article discusses Islamic scientific theology that often debated by scholars. Some Islamic scholars argue that Islam through al-Qur'an motivates believers to love science and thus their works do not contradict withal-Qur'an. Others argued that al-Qur'an only provides signs of science and encourages people to solve the puzzles of science. Nowadays the need for islamization of science has grown stronger among Islamic thinkers. This article uses a theological approach to explore the relation of science and Islam. As such, al-Qur'an not only encouraged people to love science but also the signals of science that will produce works of science that contribute to human civilization. In short, the existence of theological science gained significant support in the teachings of Islam to be an integral part of the system of Islamic theology.
\end{abstract}

Kata kunci: sains, al-Qur'an, epistemology, islamisasi, teologi saintifik 


\section{Pendahuluan}

Pengetahuan adalah keseluruhan pemikiran, gagasan dan pemahaman yang dimiliki manusia tentang dunia dan segala isinya, termasuk manusia dan kehidupannya. Sebelum filsafat dan ilmu pengetahuan berkembang, pengetahuan pra-ilmiah yang berkembang adalah mitos. Manusia menggunakan mitos untuk memberi jawaban terhadap berbagai masalah yang dihadapi manusia. Pengetahuan pra-ilmiah atau pengetahuan eksistensial dapat berbentuk dongeng, mitos, pengetahuan sehari-hari (common sense) yang bersumber dari pengalaman, rasio, intuisi, meditasi, dan pre-kognisi. Ketika jawaban yang diberikan mitos dan pengetahuan sehari-hari tidak lagi memadai dan tidak memuaskan manusia, maka muncullah upaya-upaya untuk menjelaskan fenomena alam dengan penjelasan rasional yang didasarkan atas pengalaman empiris. Dari proses ini dihasilkanlah berbagai pengetahuan sesuai dengan kebutuhan manusia.

Epistemologi atau teori pengetahuan (theory of knowledge) adalah bidang filsafat yang membahas secara filosofis (kritis dan mendasar) tentang berbagai jenis pengetahuan itu. Sedangkan ilmu pengetahuan merupakan jenis pengetahuan itu. Ilmu pengetahuan merupakan jenis pengetahuan yang memiliki ciri-ciri dan metode serta sistematika tertentu. Dengan demikian cukup jelas bahwa pengetahuan (knowledge) lebih luas dari ilmu pengetahuan (science). Ilmu pengetahuan hanya salah satu jenis pengetahuan yang memiliki ciri-ciri khusus. Akhyar Yusuf Lubis telah membedakan pengetahuan (knowledge) dan ilmu pengetahuan (science) pada aspek tujuan dan metodenya. Knowledge lebih berorientasi pada pengetahuan sehari-hari sehingga merupakan bentuk pengetahuan yang digunakan untuk kepentingan sehari-hari. Sedangkan science adalah pengetahuan yang dicanangkan untuk menemukan kebenaran, memperluas pemahaman atau pengetahuan, mendeskripsi, eksplanasi, interpretasi, prediksi, retrodiksi, penemuan, aplikasi, dan kontrol. Dari aspek metode, knowledge adalah pengetahuan yang dapat diperoleh secara mudah dengan tanpa menggunakan metode-metode tertentu, sedangkan science adalah pengetahuan yang dihasilkan dengan menggunakan metode-metode ilmiah, semisal metode kualitatif maupun kuantitatif. ${ }^{1}$

Thomas Huxley berpendapat bahwa inti ilmu pengetahuan (science) tidak lebih dari akal sehat yang telah terlatih dan tertata. Perbedaannya seperti perbedaan antara seorang veteran dengan seorang prajurit baru; dan metode-metode ilmiah berbeda dari akal sehat, seperti perbedaan antara serangan seorang prajurit yang memiliki senjata dan teknologi modern dengan serangan orang primitif yang bersenjata pentungan. ${ }^{2} \mathrm{Hal}$ itu berarti bahwa untuk menghasilkan pengetahuan yang bisa dikategorikan sebagai sains,

${ }^{1}$ Akhyar Yusuf Lubis, Epistemologi Fundasional: Isu-isu Teori Pengetahuan, Filsafat Ilmu Pengetahuan, dan Metodologi (Jakarta: Akademia, 2009), h. 82-83.

${ }^{2}$ Donald B. Calne, Batas Nalar: Rasionalitas dan Perilaku Manusia, terj. Prakitri Simbolon (Jakarta: Gramedia, 2004), h. 206. 
seseorang harus melakukan seperangkat proses yang melibatkan observasi, hipotesis, eksperimen, dan sebagainya.

Generasi Islam pada abad ke-6 hingga 11 telah tercatat sebagai generasi pelopor dalam bidang sains dan filsafat. Mereka aktif dalam mengkaji dan menghasilkan penemuanpenemuan saintifik yang memberi manfaat bagi kehidupan manusia sedunia. Sebutlah misalnya al-Idrîsî (1100-1160) sebagai pakar geografi yang terkenal dengan karya petanya. Peta alIdrisi telah dijadikan rujukan selama tiga abad oleh pakar geografi dunia seperti Baker dan Stanley. Peta al-Idrîsî juga telah menjadi rujukan para pelayar-pelayar di zamannya dan sesudahnya. ${ }^{3}$ Dengan demikian tidak sedikit jasa sains Islam dalam konteks renaissance dan humanism di Barat pada abad ke-16. ${ }^{4}$ Kita juga masih ingat Jabîr ibn Hayyan al-Azdî al-Thûsî al-Sufî (722-804) yang di Barat dikenal sebagai 'Geber', sebagai seorang penggagas kimia Islam dari Kufah, Irak. Al-Jabîr telah menulis kurang lebih 112 buku. Di sisi lain terdapat Abû Yûsuf Ya'qûb ibn Ishaq al-Kindî (801-873) yang di Barat dikenal sebagai ‘alKindus'. Al-Kindî dikenal sebagai filosof Arab yang meng-hasilkan sekitar 207 buku dalam berbagai bidang seperti logika, filsafat, fisika, cabang matematika, musik, pengobatan, dan sejarah. Ada juga yang menekuni bidang matematika seperti Muhammad ibn Mûsa al-Khawarizmî (780-850) sehingga teorinya terus dipakai di Barat yakni 'Teori al-Jabar', dan banyak lagi ilmuan Muslim yang berkiprah dalam dunia sains sekaliber mereka. ${ }^{5}$

Bercermin kepada para saintis Muslim tersebut, dapat disimpulkan bahwa Islam telah berhasil mendorong pemeluknya untuk menggeluti sains sembari menghasilkan karyakarya saintifik yang bermanfaat bagi seluruh manusia. Baik al-Idrîsî, al-Jabîr, al-Kindî, alKhawarizmî, dan semua saintis Muslim tidak pernah memiliki kekhawatiran bahwa sains yang mereka kuasai akan mengurangi keimanan mereka. Justru karena karya saintifik merekalah Barat banyak memperoleh manfaat dan dapat terus mengembangkan ilmu pengetahuan dan teknologinya. Islam seharusnya tetap diposisikan sebagai agama yang progresif dan transformatif yang senantiasa memotivasi umatnya untuk mencintai ilmu pengetahuan dan menghasilkan pengetahuan itu sendiri. Kaum Muslim juga seyogyanya dapat mempertahankan predikat mereka sebagai para pencinta ilmu pengetahuan dan terus-menerus melahirkan pengetahuan baru sesuai dengan zaman mereka. Namun menjadi aneh manakala terdapat fenomena bahwa kaum Muslim kurang bersemangat untuk menghasilkan pengetahuan baru, dan atas kemandekannya tersebut mereka mulai asing dengan pengetahuan baru yang datang dari luar mereka dan semua ini berujung pada terjadinya dikotomi antara ilmu pengetahuan dan agama. Ada keraguan dan prasangka pada sebagian

${ }^{3}$ Samuel Parson Scott, History of the Moorish Empire in Europe (Philadelphia: Lippincott, 1904), h. 461-2.

${ }^{4}$ Jan P. Hogendijk, "Introduction," dalam Jan P. Hogendijk and Abdelhamid I. Sabra (ed.) The Enterprise of Science in Islam: New Perspectives (Cambridge: Massachusetts Institute of Technology, 2003), h. vii.

${ }^{5}$ Seyyed Hossein Nasr, Science and Civilization in Islam (Chicago: ABC International Group, 2001), h. 42-45. 
kaum Muslim akan pengetahuan ilmiah yang datang dari luar mereka seraya mengembangkan paradigma selektif yakni; "Apakah pengetahuan ini merusak iman atau tidak?"

\section{Perdebatan tentang Relasi Sains dan Agama dalam Islam}

Dunia telah mengakui bahwa sains Islam pada generasi Muslim abad ke-7 hingga kisaran abad ke-16 telah memiliki kontribusi besar bagi kemajuan peradaban Barat. Mereka begitu identik dengan capaian-capaian positif sains. Mereka lahir dan berkembang persis ketika Barat sedang berada dalam masa kegelapan (the Dark Age). Mereka bukan saja mempelajari sains-sains dari Yunani, akan tetapi mereka memberikan koreksi dan produk sains baru sebagai penyempurna dari sains Yunani sebelumnya. ${ }^{6}$ Hal inilah yang menyebabkab perkembangan sains Islam pada saat itu begitu pesat.

Pada era kontemporer, penerimaan Umat Islam terhadap capaian sains modern juga terus berlangsung. Morgan Clarke dalam kajiannya menyebutkan bahwa Umat Islam tidak anti terhadap sains sebagaimana yang dituduhkan kaum sekuler modern. Sebagai contoh adalah penerimaan Umat Islam di Timur Tengah terhadap teknik pembuahan in vitro fertilisation (IVF) atau "bayi tabung", yang menggabungkan sel sprema dengan ovum di luar tubuh untuk kemudian dimasukkan ke dalam rahim wanita, hingga proses kelahirannya. Saudi Arabia, Yordania, dan Mesir merupakan negara-negara Muslim yang lebih dahulu menerima temuan sains tersebut, dan bahkan kelahiran pertama dengan teknik IVF tersebut diakui telah terjadi di Mesir pada tahun 1986. ${ }^{7}$ Demikian juga keterlibatan para ilmuwan dan ulama Muslim di Cina untuk mendiskusikan kebersihan, nutrisi, dan cara hidup sehat untuk penanganan SARS merupakan implementasi dari spiritualitas sains yang terdapat dalam al-Qur'an dan Hadis. ${ }^{8}$ Bahkan menurut Marcia C. Inhorn dan Gamal I. Serour, Islam merupakan sistem keagamaan yang memuat praktek pengobatan. Islam secara umum mendorong penggunaan sains dan biomedis untuk mengurangi penderitaan. ${ }^{9}$

Jika memperhatikan prestasi sains kaum Muslim tersebut, maka sebenarnya tidak perlu ada wacana integrasi antara sains dan Islam. Melalui para saintis Muslim tersebut cukuplah bagi umat Islam untuk menegaskan bahwa memang tidak ada pertentangan antara sains dan agama dalam Islam. Muzaffar Iqbal menyebutkan bahwa pertumbuhan dan perkembangan sains dalam Islam diinspirasi oleh petunjuk-petunjuk al-Qur'an.

${ }^{6}$ George Saliba, Islamic Science and the Making of the European Renaissance (London: The MIT Press, 2007), h. 193.

${ }^{7}$ Morgan Clarke, "Science and Social Change," dalam Amyn b. Sajoo (ed.) A Companion to Muslim Cultures (London: I.B.Tauris \& Co. Ltd., 2012), h. 103.

${ }^{8} \mathrm{Jianping}$ Wang, "Discourse of Hygiene in Islam: Response of the Muslims in China to SARS Event/Islamski Dyskurs Na Temat Higieny: Chinscy Muzulmanie a Kwestia SARS," dalam Annales Universitatis Mariae Curie-Sklodowska, Vol. 19, No. 2, 2012, h. 71.

${ }^{9}$ Marcia C. Inhorn dan Gamal I. Serour, "Islam, Medicine, and Arab-Muslim Refugee Health in America After 9/11," dalam The Lancet, Vol. 378, No. 3, 2011, h. 935. 
Bahkan matematika dan astronomi sangat berkaitan teori kosmologi dalam al-Qur'an atau teori 'hay' $a$ '. ${ }^{10} \mathrm{Al}$-Qur'an memang bukan kitab matematika, astronomi ataupun pengobatan, akan tetapi ayat-ayat di dalamnya menginspirasi para saintis untuk membuktikan dan melahirkan inspirasi sains yang terdapat di dalamnya. ${ }^{11}$

Pertentangan antara agama dan sains sebenarnya lebih populer terjadi dalam tradisi keagamaan Kristen yang pada awal abad ke-19 telah melahirkan kelompok fundamentalis Kristen. Pertentangan pada saat itu dipicu oleh Teori Evolusi Darwin yang dinilai telah mencabik-cabik keimanan Kristen. Menurut Ernst Mayr, Teori Evolusi Darwin didasarkan pada lima observasi pokok antara lain; spesies memiliki kesuburan yang luar biasa, mereka membuat lebih banyak cabang daripada tumbuh menjadi dewasa, (2) Ukuran populasi diperkirakan tetap sama, dengan model yang berubah-ubah, sumber makanan terbatas, tetapi secara umum tetap pada setiap saatnya. Dalam kontek ini terdapat perjuangan di antara individu untuk bertahan hidup, dalam reproduksi spesies secara seksual, secara umum tidak ada dua individu yang sama. Pada umumnya bervariasi, dan kebanyakan variasi ini dapat diwariskan. ${ }^{12}$ Argumen-argumen demikian yang telah dianggap meruntuhkan keyakinan tentang penciptaan alam oleh Tuhan. George M. Marsden menyebutkan bahwa kaum fundamentalis menilai teori evolusi telah mengakibatkan krisis spiritual dan kultural serta merongrong fondasi Bibel dalam peradaban Amerika. ${ }^{13}$

Menguatnya wacana integrasi sains dengan Islam cukup beralasan manakala diletakkan dalam bingkai wacana "krisis sains" yang telah terjadi di negara-negara Barat. Sains yang seharusnya menjadi alat "penyelamat dan mempermudah" kehidupan manusia, secara di luar dugaan telah menjadi kekuatan jahat yang mengancam eksistensi manusia itu sendiri sebagai pencetus sains. Perkembangan sains justru menjadi kekuatan perusak dapat menghancurkan keseimbangan alam semesta. Pesatnya teknologi berbasis produksi yang mengakibatkan menipisnya sumber daya alam, target pendapatan perkapita yang menekan lingkungan, limbah yang tak terkendali, serta bahaya nuklir, senjata kimia dan biologi, merupakan bentuk ancaman sains bagi kehidupan manusia masa depan. ${ }^{14}$ Dalam konteks

${ }^{10}$ Muzaffar Iqbal, Science and Islam (New York: Greenwood Press, 2007), h. 10.

${ }^{11}$ Muhammad Saed Abdul-Rahman, Islam: Questions and Answers, The Qur'an and its Sciences (London: MSA Publication Limited, 4 Bello Close, 2003), h. 24.

${ }^{12}$ Ernst Mayr, "Charles Darwin's Theory of Evolution: Brief Summary," dalam http://www. spaceandmotion.com/Charles-Darwin-Theory-Evolution.htm, (diakses 17 January, 2013). Argumenargumen demikian yang telah dianggap meruntuhkan keyakinan tentang penciptaan alam oleh Tuhan. Lihat juga Joe E. Morris, Revival of the Gnostic Heresy: Fundamentalism (New York: Palgrave Macmillan, 2008), h. 70.

${ }^{13}$ George M. Marsden, Fundamentalism and American Culture (New York: Oxford University Press, 2006), h. 4-7. Lihat juga Harriet A. Harris, Fundamentalism and Evangelicals (New York: Oxford University press, 2008), h. 20, dan Michael Amaladoss, SJ., "Responding to Fundamentalism," dalam Asian Christian Review, Vol.1, No.1, 2007, h. 33. Lihat juga Morris, Revival of the Gnostic Heresy, h. 70 .

${ }^{14}$ Ziauddin Sardar, The Touch of Midas (India: The Other India Press, 1984), h. 1. 
ini menjadi relevan apa yang dinyatakan Osman Bakar bahwa terdapat perbedaan antara jalan modern dengan jalan Islam dalam hal kearifan lingkungan. Manusia modern melalui jalan pahit dengan penggunaan teknologi yang mengundang polusi dan kerusakan lingkungan. Mereka tidak memahami betapa pentingnya keseimbangan lingkungan bagi manusia. Sementara Islam mengenal kearifan lingkungan melalui agama di mana keseimbangan lingkungan dan kesejahteraan merupakan hal utama. Kearifan lingkungan merupakan bagian integral dari keyakinan keagamaan Islam. ${ }^{15}$

Fenomena integrasi sains dan agama dalam dunia Islam memiliki beragam sikap dan respons umat Islam. Secara umum mereka dapat dibagi ke dalam tiga kelompok; pertama adalah mereka yang menerima sains seraya menginterasikan sains ke dalam Islam. Islam dipandang sebagai agama yang mendukung perolehan pengetahuan. Sains modern adalah pengetahuan dan perolehan pengetahuan adalah kewajiban bagi kaum beriman. ${ }^{16}$ Termasuk dalam kecenderungan ini adalah gagasan Seyyed Hossein Nasr tentang pembentukan sains Islam. ${ }^{17}$ Sementara yang kedua adalah kaum Muslim yang menolak sains dan terus memposisikan sains secara dikotomis dengan Islam. Ketiga, tercermin dalam kegairahan umat Islam untuk memberikan nafas agama pada sains yang secara populer dikenal dengan wacana "islamisasi sains". ${ }^{18}$ Tiga kelompok ini senantiasa menghiasi perdebatan seputar hubungan Islam dengan sains modern. Pemahaman mereka dalam hal itu berimbas pada cara pandang mereka terhadap peradaban Islam dan peradaban Barat serta hubungan antar keduanya.

Penerimaan umat Islam terhadap sains di era modern pada awalnya dihubungkan dengan fenomena ketertarikan Sayyid Ahmad Khan (1817-1898) dan Jamaluddin al-Afghani (1838/9-1897) terhadap sains modern. Sayyid Ahmad Khan ingin meletakkan dasar ilmu baru bagi kalam. Secara pribadi Khan yakin bahwa Islam dan sains modern secara sempurna adalah selaras, dan bahwa yang diinginkan adalah penafsiran kembali untuk menunjukkan bahwa karya Tuhan (alam dan hukum-hukumnya) adalah sesuai dengan firman Tuhan (al-Qur'an). Untuk membuktikan argumennya, Khan menulis tafsiran baru atas al-Qur'an. Namun sayangnya Khan tidak memiliki kualifikasi minimum untuk menafsirkan semisal sumber-sumber Arab, pengetahuan tentang hadis, dan landasan menyeluruh tentang ilmu tafsir. ${ }^{19}$ Akibatnya, kerja-kerja Khan belum selesai secara sempurna akan tetapi cukuplah apa yang menjadi pandangannya tentang agama dan sains mewakili kelompok petama ini.

${ }^{15}$ Osman Bakar, "Environmental Health and Welfare as an Important Aspect of Civilizational Islam," dalam Mohamed Ajmal Abdul Razak (ed.) Islam Hadhari: Bridging Tradition and Modernity (Kuala Lumpur: International Institute of Islamic Thought and Civilization [ISTAC], 2009), h. 27-29.

${ }^{16}$ Iqbal, Science and Islam, h. 141.

${ }^{17}$ Ali Zaidi, Islam, Modernity, and the Human Sciences (New York: Palgrave Macmillan, 2011), h. 54.

${ }^{18}$ Seyyed Hossein Nasr, "Islam and Modern Science," bahan perkuliahan pada Pakistan Study Group, sumber http://www.muslimphilosophy.com/ip/nasr1.htm, 5 (accessed, 12 Mei 2013).

${ }^{19}$ Iqbal, Science and Islam, h. 144. 
Selain Khan, Jamal al-Dîn al-Afghânî adalah tokoh yang memiliki kesamaan dengan Khan dalam memandang hubungan agama dan sains. Al-Afghânî begitu tertarik dengan sains modern dan sangat tertarik dengan pembaharuan dalam dunia Islam. Bagi al-Afghani, sains itu baik karena ia dapat memberikan kekuatan. Al-Afghânî juga menyatakan bahwa sains itu pada mulanya datang dari dunia Islam dan oleh karenanya Islam sangat responsibel terhadap kepemilikan Barat atas sains hingga dominasinya atas dunia Islam. Karena itu menurut al-Afghânî, umat Islam harus meng-klaim kembali sains tersebut untuk meraih kemenangan sehingga umat Islam dapat membangun peradaban yang kuat. Kecenderungan al-Afghânî adalah menyesuaikan antara pengetahuan dalam Islam yakni al-'ilm dengan science. Seperti yang dikatakan oleh Nasr, akibat dari pandangan al-Afghânî ini, selama seratus hingga lima ratus tahun umat Islam melahirkan sedikit sekali sejarawan ilmu pengetahuan dan filosof ilmu pengetahuan. Sebaliknya, pada masa-masa itu umat Islam banyak memunculkan ilmuan (scientists) dan insinyur (engineers). ${ }^{20}$

Al-Afghani menegaskan - seperti yang dikutip oleh Nikki R. Keddi-bahwa siapa yang melarang ilmu dan pengetahuan dengan keyakinan bahwa mereka melindungi agama Islam adalah benar-benar musuh agama. Agama Islam adalah agama yang sangat dekat dengan ilmu dan pengetahuan, tidak ada ketidaksesuaian antara ilmu dan pengetahuan dengan dasar-dasar keyakinan Islam. ${ }^{21}$ Pandangan al-Afghânî tersebut begitu relevan dengan peran ketokohannya dalam konteks pembaharuan Islam. Al-Afghânî menyaksikan realitas umat Islam yang statis dan berkembangnya budaya taklid. ${ }^{22}$ Bagi al-Afghânî, salah satu cara yang tepat untuk mengentaskan kemunduran Islam ini adalah perlunya umat Islam mencintai sains sebagaimana halnya generasi Muslim abad ke-7.

Dalam konteks penerimaan umat Islam terhadap sains, dapat disaksikan sebuah karakter yang ekstrim seperti yang dilakukan oleh Kemal Ataturk (1881-1938). Ataturk melakukan penerimaan sains dan budaya Barat secara membabi-buta yang kesemuanya tampak pada cara Ataturk dalam mengadopsi sains dan sekularisme dari Barat. Namun demikian, Ataturk memiliki pandangannya sendiri yang menyebabkannya berbuat demikian. Pertama Ataturk menginginkan Turkey menjadi sebuah 'negara modern sekuler'. Untuk dapat mewujudkan hal tersebut, maka yang harus dilakukan adalah mempelajari sejarah ilmu pengetahuan Barat. Oleh karenanya, Ataturk kemudian mengirimkan beberapa orang untuk mengikuti perkuliahan doktor pada Universitas Harvard pada disiplin keilmuan sejarah sains. ${ }^{23}$ Apa yang menjadi mimpi Ataturk sebenarnya tidak jauh dari sekularisasi yang sering membuat dirinya cukup kontroversial dalam banyak hal. Setidaknya ia me-

${ }^{20}$ Nasr, "Islam and Modern Science," h. 3.

${ }^{21}$ Nikki R. Keddie, Sayyid Jamal ad-Din al-Afghani: A Political Biography (Berkeley: University of California, 1972), h. 104-105.

${ }^{22}$ Fazlur Rahman, Islam, terj. Ahsin Muhammad (Bandung: Pustaka, 1984), h. 315. Lihat juga Harun Nasution, Islam Ditinjau dari Berbagai Aspeknya (Jakarta: UI Press, 1986), h. 109.

${ }^{23}$ Nasr, "Islam and Modern Science," h. 3. 
mimpikan Turki sebagai negara layaknya negara-negara Barat pada umumnya yang tidak memiliki simbol-simbol keagamaan.

Kelompok kedua adalah kelompok umat Islam yang menolak sains di mana kelompok ini kemudian banyak terdapat pada kelompok ulama' meskipun tidak semuanya. Mereka menolak pandangan modernis dan mendasarkan pandangannya pada pelaksanaan syariah. Sebagai contoh adalah kasus Nawab Alauddin, salah seorang penguasa di negara feodal India. Alauddin menolak teleskop karena dianggap dapat merusak keimanan dan menentang Nabi Muhammad. ${ }^{24}$ Sedangkan menurut Nasr, kelompok ini pada awalnya terdapat dalam pemikiran dan gerakan Wahabi khususnya pada abad ke-19 yang menentang sains modern dan teknologi. Namun demikian, menurut Nasr transformasi besar-besaran telah terjadi di mana di negara Saudi Arabia saat ini memiliki program terbaik yakni pengajaran sains dan teknologi di dunia Islam. ${ }^{25}$ Namun demikian, kelompok ini tidak berkembang dan dapat dikatakan hilang dari peredaran peta pemikiran Islam oleh karena tingginya kecenderungan Umat Islam untuk mengaplikasikan sains dalam kehidupan mereka sehari-hari.

Kelompok ketiga adalah umat Islam yang berpandangan bahwa upaya ilmu pengetahuan di Barat lahir dari latar belakang sejarah tertentu; hal ini sangat terkait dengan lembaga lain dari peradaban Barat, dan terlepas dari klaimnya untuk universalitas, ia adalah buatan peradaban Barat. Dengan demikian ia telah berakar secara mendalam dalam sebuah pandangan dunia yang berbeda dengan Islam. Dalam kenyataannya, tidak hanya sains akan tetapi semua pengetahuan modern telah dianggap memerlukan koreksi epistemologis. ${ }^{26}$ Mereka berinisiatif untuk melahirkan sains yang bernafaskan Islam. Inisiatif dan pemikiran seperti ini melahirkan sebuah iktikad yang kemudian lebih dikenal sebagai Islamisasi sains. Dipelopori oleh Ismail al-Faruqi (1921-1986), sebuah gerakan yang didasarkan pada anggapan bahwa penyebab kemunduran dunia Islam adalah "sistem pendidikan" yang mendua ke dalam dua subsistem, satu sisi "modern" sedang sisi lain "Islamis." Untuk memperbaiki kelesuan ini, al-Faruqi berusaha menyatukan dua sistem pendidikan tersebut dan mengislamkan pengetahuan. Gagasan "islamisasi ilmu" oleh Ismail al-Faruqi yang secara umum memiliki fokus pada islamisasi ilmu-ilmu sosial dan humanisme. ${ }^{27}$

Nasr yang tergolong dalam kelompok ini berpendapat bahwa sains Islam bukan merupakan bagian dari sains Barat, akan tetapi merupakan sebuah cara yang independen dalam melihat kerja alam. Jika sains Barat banyak berhubungan dengan peradaban Barat, maka sains Islam tentu saja banyak berhubungan dengan peradaban Islam. Prinsipnya adalah bahwa sains bukalah aktivitas yang bebas nilai. Di samping itu, adalah layak dan memungkinkan bagi sebuah peradaban untuk dapat mempelajari sains dari peradaban

\footnotetext{
${ }^{24}$ Ehsan Masood, Science and Islam: A History (London: Icon Books, 2009), h. 201.

${ }^{25}$ Nasr, "Islam and Modern Science," h. 5.

${ }^{26} \mathrm{Iqbal}$, Science and Islam, h. 167.

${ }^{27}$ Zaidi, Islam, Modernity, and The Human Sciences, h. 54.
} 
lain. ${ }^{28}$ Dengan demikian, secara epistemologis dan aksiologis terdapat perbedaan antara sains Barat dan sains Islam. Secara epistemologi sumber kajian masing-masing sains tersebut berasal dari peradaban yang berbeda, sedangkan secara aksiologis sains Islam tidak mengenal adagium "sains bebas nilai".

Secara epistemologis, seni dan pengetahuan dalam Islam didasarkan pada ide tentang kesatuan yang menjadi jantung bagi pewahyuan Islam. Seperti semua seni Islam yang murni, apakah di al-Hambra atau Masjid di Paris memberikan bentuk plastik di mana seseorang dapat merenungkan keesaan Tuhan yang memanifestasikan diri-Nya dalam keragaman, sehingga semua pengetahuan secara tepat dapat disebut Islami. Seseorang bisa berkata bahwa tujuan semua pengetahuan Islam - termasuk semua pengetahuan alam pada masa pertengahan dan klasik - menunjukkan kesatuan dan keterhubungan pada semua yang ada, oleh karena itu, dalam merenungkan kesatuan alam, manusia bisa diarahkan pada kesatuan prinsip ketuhanan, di mana kesatuan alam adalah gambarannya. ${ }^{29}$ Dengan demikian secara epistemologis ada relasi antara wahyu dan kesatuan alam terhadap tujuan semua itu yakni pengenalan lebih dekat terhadap Tuhan.

Dipandang sebagai teks, alam adalah simbol, yang harus dibaca sesuai dengan maknanya. Al-Qur'an adalah mitra teks dalam kata-kata manusia; ayat-ayatnya disebut âyat (tanda), seperti fenomena alam. Keduanya, alam dan al-Qur'an berbicara seterusnya tentang kehadiran dan penyembahan pada Tuhan. "Kami akan memperlihatkan kepada mereka tanda-tanda (kekuasaan) Kami di segenap ufuk dan pada diri mereka sendiri, sehingga jelaslah bagi mereka bahwa al-Qur'an itu adalah benar. Dan apakah Tuhanmu tidak cukup (bagi kamu) bahwa sesungguhnya Dia menyaksikan segala sesuatu?". ${ }^{31}$ Untuk para Doktor Hukum, teks ini hanya preskriptif, alam hadir dalam pikiran mereka hanya sebagai pengaturan yang diperlukan untuk tindakan manusia. Bagi kalangan sufi, di sisi lain, teks al-Qur'an juga bersifat simbol, seperti seluruh alam adalah simbol. Jika tradisi interpretasi simbolik atas teks Kitab Suci telah hilang, dan teks selanjutnya direduksi menjadi arti harfiahnya, manusia masih mengetahui kewajibannya, tetapi teks alam pasti bisa dipahami. ${ }^{32}$

Ayat yang dikutip oleh Nasr di atas merupakan sebuah sinyalemen tentang adanya relasi antara agama dan sains. Melalui prinsip relasi atau keterhubungan antara al-Qur'an, alam semesta, dan pengetahuan manusia maka dalam visi sains Islam sebenarnya tidak ada dikotomi dan polaritas antara al-Qur'an, alam semesta, dan pengetahuan manusia. Sains Islam hendaknya dapat mengungkap teka-teki sains seperti yang sudah tersirat dalam al-Qur'an maupun dalam fenomena alam semesta. Dengan demikian, Islam dan sains tidak memiliki pertentangan. Jika terdapat indikator pertentangan, maka pertentangan

\footnotetext{
${ }^{28}$ Nasr, "Islam and Modern Science," h. 6.

${ }^{29} \mathrm{Nasr}$, Science and Civilization in Islam, h. 22.

${ }^{30}$ Ibid., h. 24.

${ }^{31}$ Q.S. Fushshilat/41: 53.

${ }^{32}$ Nasr, Science and Civilization in Islam, h. 24.
} 
itu sebenarnya bukanlah pertentangan pada ranah intelektualnya akan tetapi pada ranah etisnya. Penyalahgunaan bom dan perang teknologi pada perang di Teluk Persia yang banyak menewaskan banyak orang bukanlah kesalahan sains modern itu sendiri akan tetapi merupakan kesalahan etis dalam menerapkan sain modern. ${ }^{33}$ Sebagai tugas penting dari sains Islam adalah memberikan warna pada tataran epistemologisnya sehingga secara aksiologis sebuah sains dapat memberikan manfaat dan bukannya menjadi kekuatan destruktif bagi manusia dan alam semesta.

Namun demikian, meski banyak ayat-ayat al-Qur'an yang membicarakan tentang proses penciptaan kosmos dan cabang pengetahuan lainnya, hal itu tidak harus dimaknai bahwa al-Qur'an merupakan Kitab yang memiliki kandungan sains. Nidhal Guessoum menyatakan bahwa al-Qur'an memang banyak menyiratkan penciptaan alam semesta dan memerintahkan manusia untuk mencari pengetahuan dengan cara mengamati dan membaca. Namun demikian, Guessoum tergolong pakar yang menolak pandangan bahwa dalam al-Qur'an terdapat kandungan sains. Menurutnya, konsep sains dalam pemahaman modern tidak mudah ditemukan dalam al-Qur'an ataupun hampir di semua warisan Muslim klasik apalagi dikembangkan. Terdapat kebingungan atas dua konsep yang dibuat oleh pemikir dan pendidik yakni kata 'ilm yang secara terus-menerus digunakan untuk istilah science. Dengan demikian, ide tentang 'scientiûc content' (kandungan sains) dalam al-Qur'an menurut Guessoum harus ditolak. ${ }^{34}$

Lebih lanjut, Guessoum menggunakan teori I'jâz (perumpamaan) untuk memperkuat argumennya. Dengan menggunakan pendekatan I'jâz, Guessoum berpendapat bahwa ayat-ayat al-Qur'an yang berisi proses penciptaan semesta dapat dipahami sebagai kiasan bagi alam semesta. Sebagai contoh misalnya, ayat "Dia berkata kepadanya (langit) dan kepada bumi: "Datanglah kamu keduanya menurut perintah-Ku dengan suka hati atau terpaksa" (Q.S. Fushhilat/41: 11) menurut Guessoum merupakan kiasan untuk penciptaan alam semesta. Demikian juga ayat "Kemudian Kami jadikan saripati itu air mani (yang disimpan) dalam tempatyang kokoh" (Q.S. Mu'minûn/23: 13) menurut Guessoum merupakan kiasan untuk proses pembentukan embrio manusia. ${ }^{35}$

Penolakan Guessoum pada pandangan bahwa terdapat kandungan sains dalam al-Qur'an ini sejalan pandangan Muhammad Saed Abd. Rahman yang berkali-kali menegaskan bahwa al-Qur'an bukanlah kitab sains. Bagi Rahman, al-Qur'an bukanlah kitab pengobatan atau astronomi meskipun ayat-ayat di dalamnya berisi sedikit hal-hal itu. Menyatakan bahwa beberapa obat-obatan ditemukan dalam al-Qur'an dinilainya sebagai berlebihan. Dalam al-Qur'an Allah menyebutkan madu berfungsi penyembuhan bagi manusia. Jika dikatakan bahwa al-Qur'an berbicara mengenai pengobatan dalam konteks ini hal itu dapat

\footnotetext{
${ }^{33}$ Nasr, "Islam and Modern Science," h. 5.

${ }^{34}$ Nidhal Guessoum, Islam's Quantum Question: Reconciling Muslim Tradition and Modern Science (London: I.B.Tauris and Co Ltd, 2011), h. 63-64.

${ }^{35}$ Ibid., h. 171.
} 
dibenarkan. Akan tetapi memperluas penilaian dari kasus kecil ini sehingga terbangun kesimpulan bahwa al-Qur'an merupakan Kitab pengobatan merupakan sesuatu yang tidak dapat dibenarkan. Rahman tetap memposisikan al-Qur'an sebagai Kitab petunjuk dan mukjizat terbesar bagi umat manusia. ${ }^{36}$ Dalam karyanya yang lain Rahman menjelaskan bahwa Islam adalah agama pengetahuan yang memerintahkan umatnya untuk memperoleh pengetahuan dan mempelajari apa yang telah Allah anugerahkan kepada manusia. ${ }^{37}$

Rana Dajani menjelaskan bahwa Islam memerintahkan kita untuk menggunakan metodologi dan logika sains untuk memahami lingkungan di sekitar manusia. Al-Qur'an berisi ayat-ayat yang menggambarkan kejadian dunia di mana ayat-ayat ini disampaikan dengan nyata dan menakjubkan dan dalam penciptaan alam semesta. Tetapi al-Qur'an bukan Kitab sains. Jika terdapat kejadian yang tampak bertentangan antara sebuah ayat dalam al-Qur'an dan fakta ilmiah, maka yang harus dilakukan adalah merevisi konklusi ilmiah yang tidak memiliki kebenaran mutlak dan penafsiran atas ayat-ayat al-Qur'an tersebut. ${ }^{38}$

Sebagai petunjuk hidup bagi manusia, al-Qur'an memberikan motivasi yang besar bagi manusia untuk memperoleh pengetahuan yang dapat memberi manfaat bagi kehidupannya. Proses penciptaan alam, unsur-unsur pengobatan, dan petunjuk praktis bagi kehidupan sehari-hari, semuanya merupakan rangsangan sains yang diberikan al-Qur'an kepada manusia. Manusia berkewajiban mengembangkan rangsangan-rangsangan tersebut sehingga dapat menjadi sains yang terbukti dan dapat dirasakan manfaatnya bagi kehidupan manusia. Rangsangan sains ini yang diharapkan menghasilkan dampak besar bagi perkembangan sains manusia. Manusia dirangsang untuk mampu memecahkan teka-teki dan misteri sains yang terdapat di dalam al-Qur'an dan mengembangkan sains yang telah ditemukannya. Sekiranya al-Qur'an telah membuat teori-teori sains yang bersifat terapan, maka perkembangan sains tidak akan terjadi karena tentu saja manusia tidak memiliki tantangan dan problem sains tertentu.

\section{Teologi Saintifik dalam Islam}

Dalam pandangan banyak ilmuwan Muslim, Islam bukan hanya agama yang bernilai ritual dan hanya mengatur hubungan manusia dengan Tuhan saja, akan tetapi ia (Islam) banyak berkaitan dengan ilmu pengetahuan. Menurut mereka, al-Qur'an dapat didekati atau dipahami dengan menggunakan pendekatan sains. Mereka memiliki corak penafsiran dan pemahaman tersendiri yang lebih khas dan spesifik mengenai ayat-ayat

${ }^{36}$ Abdul-Rahman, Islam: Questions and Answers, h. 21-25.

${ }^{37}$ Muhammad Saed Abdul-Rahman, Islam: Questions and Answers, the Hadeeth and its Sciences (London: MSA Publication Limited, 4 Bello Close, 2003), h. 114.

${ }^{38}$ Rana Dajani, "Evolution and Islam's Quantum Question," dalam Zygon: Journal of Religion \& Science, Vol. 47, No. 2, 2015, h. 353. 
al-Qur'an khususnya ayat-ayat yang menceritakan tentang alam semesta. Para mufasir pada umumnya, seringkali mendekati al-Qur'an hanya melalui tata bahasa dan makna tekstual dari al-Qur'an, sementara para sains Muslim memberikan penafsiran sesuai dengan bidang ilmu mereka, misal ekologi, geografi, dan atom.

Bagi umat Islam, terdapat hubungan mendalam antara fenomena saintifik dan pewahyuan al-Qur'an berdasar fakta bahwa ilmu adalah sebuah studi sistematis tentang fisika alam, yang dibuat atas nama Allah yang telah mewahyukan al-Qur'an sehingga harus ada sebuah konsep sebagai sebuah kesesuaian fakta antara dua dimana pun mereka berhubungan pada seperangkat fenomena yang sama. Al-Qur'an adalah kitab petunjuk agama untu mengarahkan kehidupan kita agar sesuai dengan kehendak Allah. Tetapi al-Qur'an juga berfungsi untuk mengarahkan kita menuju keimanan kepada Allah dengan cara mengundang umat Islam untuk mengamati fenomena alam, memikirkan dan merenungkan atas ragam fenomena yang terjadi di alam semesta, sebagaimana ditandai dengan kata-kata undzurû bermakna lihat, amati (QS. al-An'am/6: 99), ya'qilûn bermakna memahami (QS. al-Nisâ'/45: 4), yatafakkarûna (QS. Âli 'Imrân/3: 191). ${ }^{39}$

Mehdi Golshani ${ }^{40}$ merupakan ilmuwan Muslim yang banyak menuangkan pemikirannya mengenai keterkaitan sains dan Islam serta dimensi-dimensi dalam al-Qur'an. Dalam sebuah artikel berjudul Can Science Dispense with Religion? yang merupakan hasil wawancara Golshani dengan Reza Davari Ardakan menyebutkan bahwa pembahasan tentang sains dan agama sering menemukan persoalan pada sisi kasus agama. Hal itu karena sains berhubungan dengan akal, sedangkan akal tidak bisa memahami kedalaman dan misteri agama, meskipun agama itu sendiri tidak asing bagi akal. Jelas bahwa umat Islam tidak menghubungkan sains dalam maknanya yang luas. Apa yang dimaksud di sini adalah sains secara keseluruhan yang di dunia modern dihubungkan dengan dunia lain, dan contoh persisnya ditemukan dalam fisika matematika. Kaum positivis memandang sains sebagai ekspresi langsung dan hubungan tertentu dari fenomena. ${ }^{41}$

Golshani menambahkan bahwa tidak ada ilmuan yang dapat menolak keberadaan dari sumber yang sakral dengan beralih pada ilmu pengetahuan, dan memandang peribadatan sebagai perilaku yang sia-sia. Tetapi terkadang terdapat konflik antara penelitian ilmiah dan kemutlakan agama. Pemikir terdahulu menyatakan bahwa jika muncul konflik antara perintah akal dan ketentuan agama, maka seseorang harus menafsirkan ketentuan agama.

${ }^{39}$ M. M. Qurashi, "Basic Concepts of Physics in the Perspective of the Quran," dalam Islamic Studies Journal, Vol. 28, No. 1, 1989, h. 55.

${ }^{40}$ Mehdi Golshani adalah Guru Besar dalam bidang Fisika pada Universitas Teknologi Syarif. Ia memperoleh gelar Doktor bidang Fisika dengan spesialisasi Partikel Fisika tahun 1969 dari Universitas California, Berkeley. Lihat http://en.wikipedia.org/wiki/Mehdi_Golshani (diakses, 12 Mei 2013).

${ }^{41}$ Mehdi Golshani, "Can Science Dispense with Religion? An interview of Reza Davari Ardakan," dalam http://www.science-islam.net/article. php3? id_article=705\&lang=en, 1 (accessed, 23 Mei 2013). 
Persepsi ini, secara khusus terdapat pada dua abad yang lalu, telah mengarah pada penafsiran pernyataan-pernyataan keagamaan yang selaras dengan fakta-fakta ilmiah yang dapat diterima secara universal. ${ }^{42}$ Golshani nampaknya sependapat dengan paradigma integrasi sains dan agama tersebut. Sebagai Kitab yang diberikan oleh Allah kepada umat manusia, tidak mungkin ada pertantangan al-Qur'an dengan hukum-hukum akal. Jika terdapat pertentangan - sepanjang hukum-hukum akal telah memenuhi kaidah-kaidahnya - maka penafsiran terhadap al-Qur'an itu yang perlu ditinjau kembali tanpa merubah al-Qur'annya.

Jika kita tinjau lebih dekat, menurut Ardakan sebenarnya tidak ada konflik antara ilmu dan agama. Sebenarnya, konflik itu antara para teolog dan para sarjana atau antara teologi dan beberapa bagian dari teori-teori ilmu pengetahuan atau penafsiran spesifik dari teori-teori ini. "Namun, dalam buku-buku teks pendidikan, dan di dalam opini mereka yang membatasi penilaian ilmu pada penyelidikan, penelitian, sanggahan, dan pembuktian atau keterujian, dan berpendapat bahwa penilaian ilmu pengetahuan dapat dibenarkan atau disetujui, atau diselidiki dan disanggah, baik secara sengaja atau sadar, mereka telah telah membuat pertentangan antara agama dan ilmu." 43

Pandangan Ardakan sebagaimana dikutip Golshani ini menegaskan adanya parameter yang berbeda antara parameter ilmu empirik dan agama. Ardakan menilai bahwa tidak semua parameter ilmu empirik dapat dijadikan parameter dalam menilai atau membuktikan argumentasi keagamaan. Jika ini dilakukan, maka sebenarnya bukan integrasi yang akan diperoleh melainkan sebuah pertentangan dan dis-integrasi. Argumentasi demikian tidak berarti bahwa antara sains dan agama tidak sejalan. Dalam seminar-seminar ataupun perkuliahan mengenai hubungan agama - khususnya Islam - dengan sains, seringkali muncul pendapat yang beragam tentang hubungan tersebut. Sebagian kaum Muslim berpandangan bahwa al-Qur'an mengandung pesan-pesan ilmu pengetahuan sehingga dapat menjadi sandaran sains dan teknologi, sedangkan yang lainnya berpandangan bahwa agama hanya menjadi kekuatan moral yang bersifat aksiologis bagi realisasi ilmu pengetahuan. Ragam pendapat tersebut sebenarnya pernah menjadi bahasan Golshani dalam The Scientific Dimension of the Quran.

Menurut Golshani, al-Qur'an merupakan kitab petunjuk bagi pembangunan manusia, dan ia berisi apapun yang dibutuhkan manusia di dalam keseluruhan iman dan perbuatan. Kita tidak memandang al-Qur'an sebagai ensiklopedi pengetahuan, tidak juga meyakini bahwa adalah benar untuk menyesuaikan al-Qur'an untuk mengubah teori-teori pengetahuan. Di sisi lain, seseorang tidak bisa mengabaikan bahwa Quran berisi rujukan untuk beberapa fenomena alam. Tetapi hal ini bukan untuk pengajaran sains; melainkan, semua itu digunakan sebagai alat bantu untuk menarik perhatian orang-orang akan Kemuliaan

\footnotetext{
${ }^{42} I b i d ., 4$.
}

${ }^{43}$ Ibid., 4. 
Allah, dengan demikian membawa mereka untuk lebih dekat kepada-Nya. ${ }^{44}$ Jika al-Qur'an dipadankan posisinya dengan ensiklopedia, tentu hal itu akan menurunkan derajat alQur'an sebagai firman Tuhan. Dengan demikian, kaum Muslim tidak perlu menjadikan al-Qur'an sebagai pemberi penilaian atau falsifikasi terhadap sains karena pada prinsipnya sains-sains yang ada merupakan sebagian artikulasi dari induk sains seperti yang disinyalir al-Qur'an. Sebaliknya, justru kemajuan sains akan membuatnya lebih mudah dalam memahami ayat-ayat al-Qur'an.

Golshani mencontohkan beberapa ayat dalam al-Qur'an misalnya, "dan apakah orangorangyang kafir tidak mengetahui bahwasanya langit dan bumi itu keduanya dahulu adalah suatu yang padu, kemudian Kami pisahkan antara keduanya. Dan dari air Kami jadikan segala sesuatu yang hidup. Maka mengapakah mereka tiada juga beriman?" (Q.S. al-Anbiyâ'/21: 30). "dan segala sesuatu Kami ciptakan berpasang-pasangan supaya kamu mengingat akan kebesaran Allah.” (Q.S. al-Dzariyât: 49)

Ayat-ayat ini menurut Golshani memberikan informasi tentang adanya polaritas dalam semua penciptaan. Sains modern membuatnya lebih mudah memahami ayat-ayat tersebut. Singkatnya, pandangan Golshani tentang interpretasi atas al-Qur'an adalah sama dengan Mustafa al-Maraghi sebagaimana yang tertuang dalam pendahuluan untuk buku Islam dan Modern Medicine karya Ismail Pasha. Dalam pendahuluannya tersebut, al-Maraghi menyatakan sebagai berikut:

Bukanlah maksud saya untuk mengatakan bahwa Kitab Suci ini mengandung, secara terperinci atau ringkasan semua pengetahuan dalam gaya buku teks; melainkan saya ingin mengatakan bahwa ia mengandung prinsip-prinsip umum dengan bantuan yang satu dapat menurunkan semua yang dibutuhkan untuk mengetahui pembangunan fisik dan spiritual kemanusiaan. .... Hal ini penting untuk tidak memperpanjang [makna] ayat sedemikian rupa bahwa hal itu akan memungkinkan kita untuk menafsirkannya dalam terang ilmu pengetahuan. Tak seorang pun harus meluruskan [penafsiran] faktafakta ilmiah sehingga orang bisa beradaptasi dengan ayat al-Qur'an. Namun, jika makna jelas dari ayat itu konsisten dengan fakta yang mapan, kita menafsirkan ayat ini dengan bantuan fakta tersebut. ${ }^{45}$

Dengan banyaknya ayat-ayat al-Qur'an yang berbicara tentang fenomena alam, menurut Golshani hal itu dapat menjadi pesan bagi para ilmuwan atau saintis. Beberapa pesan menurut Golshani adalah sebagai berikut. Pertama, studi tentang aspek-aspek alam dan penemuan akan misteri-misteri penciptaan adalah dianjurkan, kedua ayat-ayat tersebut menyatakan bahwa segala sesuatu di dunia ini tertib dan terarah dan tidak ada kesalahan dalam karya Allah, dan ketiga al-Qur'an mengundang kita untuk mengenali hukum alam dan memanfaatkannya untuk kesejahteraan manusia tanpa melanggar

\footnotetext{
${ }^{44}$ Mehdi Golshani, “The Scientific Dimension of the Quran," dalam http://www.al-islam.org (accessed, Juni 4, 2013).

${ }^{45}$ Ibid., 9.
} 
ketentuan syariah. ${ }^{46}$ Sebagai ilmuan fisika, Golshani memandang bahwa ayat-ayat alQur'an yang berbicara tentang fenomena alam mengandung misteri-misteri fisika yang dapat diungkap manakala seseorang memahami kajian fisika. Dengan demikian, Golshani telah mencoba memberikan tafsiran pada al-Qur'an setidaknya dari perspektif kajian fisika sebagai bidang kajiannya.

Dari perspektif ekologi dan ilmu lingkungan, Fazlun M. Khalid banyak mencontohkan keterkaitan antara al-Qur'an dengan lingkungan. Dalam pandangan Khalid, agama Islam dalam esensinya menggambarkan adanya hubungan kode etik yang berkaitan dengan kesehatan pribadi. Islam menyediakan pendekatan holistik terhadap segala eksistensi, Islam tidak membedakan antara yang suci dan yang sekuler dan juga perbedaan tempat antara dunia manusia dan dunia alam. ${ }^{47}$ Apa yang dimaksudkan oleh Khalid adalah bahwa dalam Islam, hubungan manusia dengan alam semesta sangatlah erat dan terkait satu dengan lainnya.

Di dalam al-Qur'an, dapat dijumpai banyak ayat yang berkaitan dengan lingkungan alam. Beberapa ayat di antaranya adalah; "yang kepunyaan-Nya-lah kerajaan langit dan bumi, dan Dia tidak mempunyai anak, dan tidak ada sekutu bagi-Nya dalam kekuasaan (Nya), dan Dia telah menciptakan segala sesuatu, dan Dia menetapkan ukuran-ukurannya dengan serapi-rapinya" (QS. al-Furqân/25: 2), dan "Dia-lah yang menjadikan matahari bersinar dan bulan bercahaya dan ditetapkan-Nya manzilah-manzilah (tempat-tempat) bagi perjalanan bulan itu, supaya kamu mengetahui bilangan tahun dan perhitungan (waktu). Allah tidak menciptakan yang demikian itu melainkan dengan hak. Dia menjelaskan tanda-tanda (kebesaranNya) kepada orang-orang yang mengetahui" (QS. Yûnus: 5).

Menurut Khalid, ayat tersebut menjelaskan bahwa Allah menciptakan alam semesta dan setiap satu atom atau molekulnya diliputi hukum-hukum penciptaan seperti unsurunsur tatanan, keseimbangan, dan proporsi. ${ }^{48}$ Dalam setiap penciptaan, dari unsur yang paling besar hingga yang paling kecil, mengandung tatanan dan sistem kehidupan yang apabila tatanan tersebut tidak terganggu maka akan menghasilkan keseimbangan. Manusia akan menikmati keseimbangan itu dalam hal berkurangnya atau tidak adanya bencana alam, sehingga mereka dapat hidup nyaman. Akan tetapi manakala tatanan tersebut dirusak oleh manusia maka kerusakan tersebut bukan hanya berakibat pada alam semesta akan tetapi akan membawa petaka bagi manusia.

Dalam perspektif ekologi Khalid, alam yang ditempati manusia adalah tanda dari ciptaan Allah sebagaimana lingkungan terdalam diri manusia. Semua itu memancar dari satu sumber dan terikat oleh hanya satu tujuan, yakni melayani kehendak Tuhan.

${ }^{46}$ Ibid., 9-11.

${ }^{47}$ Fazlun M. Khalid, "Islam and Environtment," dalam Peter Timmerman, et al., (ed.), Encyclopedia of Global Environmental Change (London: John Wiley \& Sons, Ltd, Chichester, 2002), h. 1.

${ }^{48}$ Khalid, Islam, h. 2. 
Ikatan kosmik pada inti terdalam dari setiap individu adalah ajaran ekologi Islam yang mendalam. Al-Qur'an menyatakan bahwa segala sesuatu di atas bumi telah diciptakan untuk kemanusiaan. Hal itu merupakan hadiah Tuhan (ni'mah) pada manusia, tetapi hadiah dengan tanpa persyaratan. Ujian adalah sebuah ukuran dari perbuatan ibadah manusia dalam makna yang luas. Hidup di jalan yang diridai Allah, berusaha keras dalam segala hal untuk memelihara harmoni lingkungan dalam dan luar diri manusia. ${ }^{49}$

Ketiadaan visi tentang hubungan manusia dan lingkungan alam telah menjadi penyebab utama dari kerusakan atau krisis lingkungan. Menurut Khalid, manusia modern terlepas dari keharusan menjaga tatanan alam, tampak berusaha menguasainya, banyak merugikan dirinya dan lingkungan hidup. Kapitalisme Liberal dan Sosialisme Marxist merupakan dua ideologi yang telah menciptakan dis-integrasi di dunia. Hal itu karena kedua ideologi ini telah merubah fungsi alam kepada pemenuhan kepentingan industri pada abad ke-19 dan 20. ${ }^{50}$ Menurut Khalid, dalam ikatan kosmik yang telah rusak konsumen tergoda untuk bersaing satu sama lain dalam kepemilikan gadget terbaru, televisi dan penimbunan iklan terus-menerus membuat orang merasa tidak puas, media dimanfaatkan sebagai alat manipulasi. Peradaban global kita tampak sangat palsu, bertumpu pada sistem industri dan keuangan dalam mengejar keuntungan tunggal. Ekologi manusiawi sangat runtuh. Tradisi dan kebijaksanaan zaman ditolak, digantikan oleh modernitas dan ikonik berdasarkan perbudakan manusia ke mesin. ${ }^{51}$

Perspektif lain atas dimensi-dimensi sains dalam al-Qur'an disampaikan oleh Zagloul al-Najjar. Sebagai pakar geologi, al-Najjar lebih jauh lagi di dalam meninjau ayat-ayat yang berkaitan dengan alam semesta. Dalam perspektif Zagloul, setiap ayat yang berkaitan dengan penciptaan alam semesta selalu memiliki pesan-pesan ilmu atau sains bagi manusia. Dalam bukunya Wonders of Holy Qur'an, al-Najjar membagi pembahasannya kepada tiga aspek yakni botani, geologi, serta penciptaan manusia dan alam semesta. Sebagai contoh misalnya al-Najjar memberikan tafsiran saintis terhadap kandungan ayat al-Qur'an, "Dan apakah orang-orangyang kafir tidak mengetahui bahwasanya langit dan bumi itu keduanya dahulu adalah suatu yang padu, kemudian Kami pisahkan antara keduanya. Dan dari air Kami jadikan segala sesuatu yang hidup. Maka mengapakah mereka tiada juga beriman?" (QS. al-Anbiyâ/21: 30). Terhadap ayat ini, setidaknya terdapat lima tafsiran sains menurut al-Najjar yakni;

Air mendahului eksistensi semua makhluk. Semua studi geologi telah membuktikan usia bumi lebih tua dari 4,6 miliar tahun yang lalu sedangkan usia tanda yang paling

${ }^{49}$ Fazlun Khalid, "Islam and the Environment: Ethics and Practice," dalam Religion Compass, Vol. 11, No. 4, 2010, h. 710.

${ }^{50}$ Fazlun M. Khalid, "Islam, Ecology, and Modernity: An Islamic Critique of the Root Causes of Environtmental Degradation," dalam Richard C. Foltz, et al. (ed.), Islam and Ecology: A Bestowed Trust (USA: Harvard University Press, 2003), h. 303.

${ }^{51}$ Fazlun M. Khalid, "Applying Islamic Environmental Ethics," dalam Richard C. Foltz (ed.), Environmentalism in the Muslim World (New York: Nova Science Publisher, 2005), h. 88. 
kuno kehidupan (fosil) di batuan bumi adalah 3,8 miliar tahun. Hal ini berarti bahwa memper-siapkan bumi untuk kehidupan di atas permukaannya membutuhkan waktu lebih dari 800 tahun. Allah mampu menciptakan sesuatu menjadi mudah, tetapi proses penciptaan membutuhkan waktu yang panjang untuk menolong manusia mengikuti sistem Allah di atas bumi dan untuk membuat kegunaan yang baik darinya dalam membangun kehidupan. Hal ini karena keduanya, waktu dan tempat adalah dimensidimensi materi dan keterbatasan manusia adalah bagian dari penciptaan Allah, sehingga ciptaan tidak akan pernah melampaui penciptanya. Allah berada di atas semua ciptaanNya, termasuk materi, energi, waktu dan tempat. ${ }^{52}$

Said Nursi merupakan salah satu contoh bagaimana ilmuwan Muslim berpandangan bahwa sumber pengetahuan manusia berasal dari hukum dan prinsip kosmos yang diciptakan Allah pada alam semesta. Nursi memaparkan dengan tegas bahwa prinsip-prinsip alam dan ilmu pengetahuan merupakan bagian dari prinsip-prinsip Ilahi. Hal ini berarti bahwa ilmu pengetahuan dalam segala aspeknya berasal dari Allah dalam pengertian bahwa prinsip dan hukum alam diciptakan Allah sehingga kemampuan manusia yang dapat menyimpulkan atau mengambil rumusan-rumusan ini dapat menghasilkan ilmu pengetahuan. Bagi Nursi, alam adalah sesuatu yang dicetak, bukan pencetak; rancangan, bukan perancang; obyek yang diperlakukan, bukan pelaku; hukum atau ukuran, bukan asal-muasal; dan perintah, bukan yang memerintah. Alam adalah suatu prinsip yang tidak berdaya sama sekali, dia tak lebih dari seperangkat hukum yang berasal dari Kehendak dan Kuasa Ilahi yang tidak memiliki keberadaan yang eksternal dan nyata. ${ }^{53}$ Penjelasan ini menguatkan bahwa prinsipprinsip alam semesta yang kemudian menjadi dasar bagi rumusan ilmu pengetahuan itu bukan berasal dari alam sendiri, melainkan berasal dari Allah.

Lebih lanjut Nursi menjelaskan bahwa ilmu pengetahuan berfungsi seolah-olah ia adalah indera dan "mata-mata" umat manusia yang telah menemukan ketertiban melalui deduksi dan induksi. Setiap cabang ilmu pengetahuan didasarkan atau mempelajari salah satu spesies atau bagian kehidupan. Dalam ketertiban, keserasian dan keteraturan inilah prinsip-prinsip universal ilmu pengetahuan berasal. Setiap cabang ilmu pengetahuan memuat prinsip-prinsip dan kaidah-kaidah universal yang lazim dalam keseluruhan spesies yang dipelajarinya. Universalitas dan keseragaman prinsip-prinsip ini menunjukkan luar biasanya ketertiban itu, karena jika tidak ada ketertiban maka tidak mungkin untuk menarik kaidahkaidah yang universal. Manusia bisa menemukan ketertiban itu dengan sarana mata-mata ilmu pengetahuannya dan dia akan memahami, dengan memakai sarana ilmu penge-tahuan tersebut, bahwa makro-kosmos (alam semesta) sama tertibnya dengan dirinya. Ada kebijak-

${ }^{52} Z$ Zagloul al-Najjar, "Wonders of the Ever Glorious Qur'an: Miraculous Signs in the Noble Qur'an and Their Scientific Implications," dalam http//daraltarjama.com/dt/library/pdf/Dr./ Zagloul\% (accessed, Mei 12, 2013), 65.

${ }^{53}$ Said Nursi, Sinar yang Mengungkap Sang Cahaya, terj. Sugeng Haryanto, et al. (Jakarta: RajaGrafindo Persada, 2003), h. 578. 
sanaan dalam segala sesuatu; tidak ada sesuatupun yang tidak bertujuan atau dibiarkan dengan sarananya sendiri. ${ }^{54}$

Sejalan dengan pandangan di atas, Jaferhusein I Laliwala menyebutkan bahwa sumber pengetahuan ada tiga yakni; alam, manusia (termasuk masyarakat manusia), dan sejarah manusia. Dalam konteks hubungan pengetahuan, iman, dan akal, Laliwala menjelaskan bahwa di dalam al-Qur'an, umat Islam dapat menemukan tiga hal yang saling berkaitan yakni makna pengetahuan, sumber pengetahuan, dan pengetahuan dasar alam semesta. Maka menurut Laliwala, dapat dipastikan bahwa berpikir akan pengetahuan dapat mengantar manusia pada pengenalan tanda-tanda Tuhan. ${ }^{55}$

Baik Khalid, Najjar, dan Nursi semuanya telah mencoba menggali al-Qur'an sebagai sumber ajaran Islam dan sistem teologi Islam guna memperoleh pemahaman mengenai visi maupun pemahaman sains di dalam Islam. Dalam konteks ini tidak berlebihan manakala dikatakan bahwa mereka telah berupaya mengungkap visi teologi saintifik dalam Islam. mereka bukanlah mufassir dalam pemahaman umum yang memiliki kitab tafsir tertentu, akan tetapi keahlian mereka sebagai seorang saintis memberi peluang bagi mereka untuk melahirkan perspektif lain atas kandungan al-Qur'an kaitannya dengan sains. Tentu saja mereka memiliki perbedaan dengan Guessoum dan Abdul-Rahman yang menolak adanya kandungan sains dalam al-Qur'an. Akan tetapi, ijtihad sains Khalid, Najjar, dan Nursi dapat dikatakan lebih keras karena mereka telah mengungkap ayat dan memberikan pemahaman berdasarkan sudut pandang saintifk mereka.

Dengan demikian, penafsiran atas al-Qur'an hendaknya dapat menyeimbangkan dengan perkembangan sains dan teknologi bukan dengan maksud menarik al-Qur'an agar memenuhi tuntutan sains semata-mata, akan tetapi semakin memperkuat dan meneguhkan bahwa sebagian dari keagungan al-Qur'an adalah bahwa al-Qur'an senantiasa mampu memberi nafas bagi perkembangan pengetahuan manusia. Dalam konteks inilah kiranya maksud yang paling tepat bagi ungkapan "al-Qur'an senantiasa cocok dalam setiap masa dan tempat". Tetapi ungkapan itu tidak akan berarti apa-apa manakala manusia sebagai pengemban amanah al-Qur'an tidak berupaya keras mengembangkan sains sebagaimana yang diperintahkan Allah dalam al-Qur'an dan begitu pula menghasilkan pemahaman-pemahaman yang segar yang bersumber dari al-Qur'an.

\section{Penutup}

Dalam perspektif Islam, tidak ada dikotomi dan polaritas antara sains dan agama. Wacana yang perlu dikembangkan seharusnya tidak tertumpu pada integrasi sains dan Islam. Wacana integrasi Islam dan sains bukan hanya kurang tepat pada aspek materialnya,

${ }^{54}$ Ibid., h. 580.

${ }^{55}$ Jaferhusein I Laliwala, Islamic Philosophy of Religion: Synthesis of Science Religion and Philosophy (New Delhi: Sarup and Sons, 2005), h. 21-23. 
akan tetapi secara esensi akan menimbulkan tanda tanya besar. Wacana yang seharusnya lebih dikembangkan adalah bagaimana dimensi-dimensi sains dalam Islam - atau dalam al-Qur'an - dapat diberikan tafsir dan komentar yang bersifat sains. Hal ini penting mengingat dua hal; pertama, penguatan paradigma ketiadaan dikotomi sains dan Islam, dan kedua akan menjadi spirit bagi kreasi dan inovasi kaum Muslim dalam rangka menemukan sains-sains baru yang belum ditemukan sebelumnya. Adalah suatu pandangan a-historis manakala kaum Muslim hanya bisa menyatakan bahwa al-Qur'an mengandung semua jenis pengetahuan tanpa menghasilkan sains-sains yang baru. Maka sebagai hal penting dalam artikel ini adalah sebuah konklusi bahwa eksistensi sains memperoleh dukungan teologis yang signifikan dalam ajaran Islam hingga menjadi bagian integral yang tidak terpisahkan dari sistem teologi Islam. Jika generasi Muslim abad ke-7 hingga abad ke-16 telah berjaya pada masanya dengan gemerlapnya sains yang mereka hasilkan, apakah generasi saat ini mampu mengulangi prestasi generasi saintis Muslim tersebut?

\section{Pustaka Acuan}

Amaladoss, SJ. Michael. "Responding to Fundamentalism," dalam Asian Christian Review, Vol. I, No.1, 2007.

Bakar, Osman. "Environmental Health and Welfare as an Important Aspect of Civilizational Islam," dalam Mohamed Ajmal Abdul Razak (ed.), Islam Hadhari: Bridging Tradition and Modernity. Kuala Lumpur: International Institute of Islamic Thought and Civilization (ISTAC), 2009.

Calne, Donald B. Batas Nalar: Rasionalitas dan Perilaku Manusia, terj. Prakitri Simbolon, Jakarta: Gramedia, 2004.

Clarke, Morgan. "Science and Social Change," dalam Amyn b. Sajoo (ed.) A Companion to Muslim Cultures. London: I.B.Tauris \& Co. Ltd., 2012.

Dajani, Rana. "Evolution and Islam's Quantum Question," dalam Zygon: Journal of Religion \& Science, Vol. 47, No. 2, 2015.

Golshani, Mehdi. "Can Science Dispense with Religion? An interview of Reza Davari Ardakan," dalam http://www.scienceislam.net/article.php3?id_article705\&lang= en 1. Diakses 23 Mei 2013.

Golshani, Mehdi. "The Scientific Dimension of the Quran," dalam http://www.al-islam.org. Diakses Juni 4, 2013.

Guessoum, Nidhal. Islam's Quantum Question Reconciling Muslim Tradition and Modern Science. London: I.B.Tauris and Co Ltd, 2011.

Harris, Harriet A. Fundamentalism and Evangelicals. New York: Oxford University Press, 2008.

Hogendijk, Jan P. "Introduction," dalam Jan P. Hogendijk and Abdelhamid I. Sabra (ed.). The Enterprise of Science in Islam: New Perspectives. Cambridge: Massachusetts Institute of Technology, 2003. 
MIQOT Vol. XXXIX No. 2 Juli-Desember 2015

Inhorn Marcia C. dan Gamal I. Serour. "Islam, Medicine, and Arab-Muslim Refugee Health in America After 9/11," dalam The Lancet, Vol. 378, No. 3, 2011.

Iqbal, Muzaffar. Science and Islam. New York: Greenwood Press, 2007.

Keddie, Nikki R. Sayyid Jamal ad-Din al-Afghani: A Political Biography. Berkeley: University of California, 1972.

Khalid, Fazlun M. "Islam and the Environment: Ethics and Practice," dalam Religion Compass, Vol. 11, No. 4, 2010.

Khalid, Fazlun M. "Islam, Ecology, and Modernity: An Islamic Critique of the Root Causes of Environtmental Degradation," dalam Richard C. Foltz et al. (ed.), Islam and Ecology: A Bestowed Trust. USA: Harvard University Press, 2003.

Khalid, Fazlun M. "Applying Islamic Environmental Ethics," dalam Richard C. Foltz, (ed.), Environmentalism in the Muslim World. New York: Nova Science Publisher, 2005.

Khalid, Fazlun M. "Islam and Environtment" dalam Peter Timmerman, et al. (ed.) Encyclopedia of Global Environmental Change. London: John Wiley \& Sons, Ltd., Chichester, 2002.

Laliwala, Jaferhusein I. Islamic Philosophy of Religion: Synthesis of Science Religion and Philosophy. New Delhi: Sarup and Sons, 2005.

Lubis, Akhyar Yusuf. Epistemologi Fundasional: Isu-isu Teori Pengetahuan, Filsafat Ilmu Pengetahuan, dan Metodologi. Jakarta: Akademia, 2009.

Marsden, George M. Fundamentalism and American Culture. New York: Oxford University Press, 2006.

Masood, Ehsan. Science and Islam: A History. London: Icon Books, 2009.

Mayr, Ernst. "Charles Darwin's Theory of Evolution: Brief Summary," dalam http://www. spaceandmotion.com/Charles-Darwin-Theory-Evolution.htm. Diakses 17 Januari, 2013.

Morris, Joe E. Revival of the Gnostic Heresy: Fundamentalism. New York: Palgrave Macmillan, 2008.

Nasr, Seyyed Hossein. "Islam and Modern Science," dalam http://www.muslimphilosophy. com/ ip/nasr1.htm. Diakses 12 April 2013.

Nasr, Seyyed Hossein. Science and Civilization in Islam. Chicago: ABC International Group, 2001.

Nasution, Harun. Islam Ditinjau dari Berbagai Aspeknya. Jakarta: UI Press, 1986.

Nursi, Said. Sinar yang Mengungkap Sang Cahaya, terj. Sugeng Haryanto, et al. Jakarta: RajaGrafindo Persada, 2003.

Qurashi, M.M. "Basic Concepts of Physics in the Perspective of The Quran," dalam Islamic Studies Journal, Vol. 28, No. 1, 1989.

Rahman, Fazlur. Islam, terj. Ahsin Muhammad. Bandung: Pustaka, 1984.

Rahman, Muhammad Saed Abdul. Islam: Questions and Answers, the Hadeeth and its Sciences. London: MSA Publication Limited, 4 Bello Close, 2003. 
Rahman, Muhammad Saed Abdul. Islam: Questions and Answers, the Qur'aan and its Sciences. London: MSA Publication Limited, 4 Bello Close, 2003.

Saliba, George. Islamic Science and the Making of the European Renaissance. London: the MIT Press, 2007.

Sardar, Ziauddin. The Touch of Midas. India: The Other India Press, 1984.

Scott, Samuel Parson. History of the Moorish Empire in Europe. Philadelphia: Lippincott, 1904.

Wang, Jianping. "Discourse of Hygiene in Islam: Response of the Muslims in China to SARS Event / Islamski Dyskurs Na Temat Higieny: Chinscy Muzulmanie a Kwestia SARS," dalam Annales Universitatis Mariae Curie-Sklodowska, Vol. 19, No. 2, 2012.

Zaidi, Ali. Islam, Modernity, and the Human Sciences. New York: Palgrave Macmillan, 2011. 